Document downloaded from:

http://hdl.handle.net/10251/121102

This paper must be cited as:

Hervás Oliver, JL.; Sempere-Ripoll, F.; Rojas Alvarado, RJ.; Estelles Miguel, S. (2018). Beyond product innovation: deciphering process-oriented innovators, complementarities and performance effects. Technology Analysis and Strategic Management. 30(5):582-595. https://doi.org/10.1080/09537325.2017.1347623

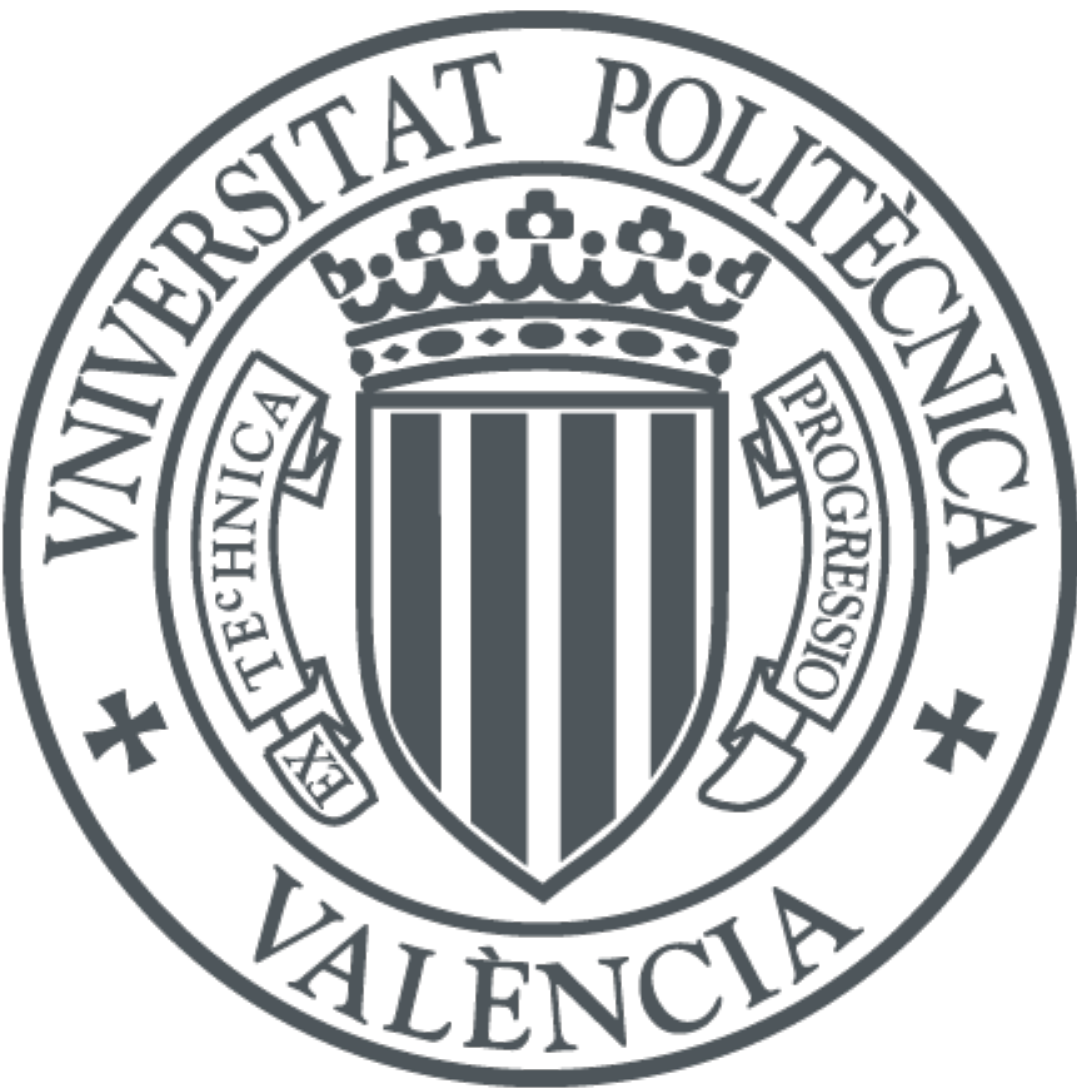

The final publication is available at

http://doi.org/10.1080/09537325.2017.1347623

Copyright Taylor \& Francis

Additional Information

This is an Accepted Manuscript of an article published by Taylor \& Francis in Technology Analysis and Strategic Management on 2018, available online:

http://doi.org/10.1080/09537325.2017.1347623 


\title{
Beyond product innovation: deciphering process-oriented innovators, complementarities and performance effects
}

\author{
Jose-Luis Hervas-Oliver* \\ Francisca Sempere-Ripoll \\ Ronald Rojas-Alvarado \\ Sofia Estelles-Miguel \\ Hervás-Oliver, José Luis* \\ Universitat Politècnica de València (Spain) \\ Campus vera s/n 7D DOE Valencia, 46022 (Spain) \\ *(corresponding author) jose.hervas@omp.upv.es \\ Sempere-Ripoll, Francisca \\ Universitat Politècnica de València (Spain) \\ Campus vera s/n Valencia, 46022 (Spain) \\ fsempere@omp.upv.es \\ Ronald Rojas Alvarado \\ Universidad ICESI, \\ Facultad de Ciencias Administrativas y Económicas \\ Departamento de Gestión Organizacional \\ Ronald.rojas@,correo.icesi.edu.co \\ Cali Colombia \\ Estelles-Miguel, Sofia \\ Universitat Politècnica de València (Spain) \\ Campus vera s/n 7D DOE Valencia, 46022 (Spain) \\ soesmi@omp.upv.es \\ Tel.: +3496387 7680 \\ Fax. +3496387 7689
}

\begin{abstract}
Relatively little attention has been paid to the understanding of process innovation, compared to the well-researched product innovation. This paper contributes to improve our understanding of process innovation and its specific process capabilities and performance by exploring, across many industries, 4,608 processoriented innovators. Process innovation is defined as adoption of technologically new or significantly improved production methods, including changes in equipment, organization or methods of product delivery. Processoriented innovators or process seekers are those firms which usually only introduce process innovation, and no product innovation. These have received less attention by scholars. Results show that process innovation without also organizational innovation complements constrains innovative performance. Complex process-based innovation complementarities result from the simultaneous development and integration of new machinery and organizational innovations.
\end{abstract}

Key words: innovation performance, process-oriented innovators, embodied knowledge, non-technical innovation, organizational innovation, resource-based view. 


\section{Beyond product innovation: deciphering process-oriented innovators, complementarities and performance effects}

\section{Introduction}

Literature has established that process innovation is important for developing competitive advantage and improving performance (e.g.: Abernathy \& Utterback, 1978; Benner \& Tushman, 2002, 2003; Linton \& Walsh, 2008), however, and despite those seminal efforts, relatively little attention has been paid to the understanding of specific process innovation strategy and its related process-based innovation performance (Hervas-Oliver and SempereRipoll, 2015; Fagerberg, Mowery, \& Nightingale, 2012; Frishammar, Kurkkio, Abrahamsson, \& Lichtenthaler, 2012; Keupp, Palmie, \& Gassmann, 2012) and process-based capabilities (Robertson, Casali, \& Jacobson, 2012), at least compared to the well-studied product innovation. Besides, when studying process innovation, there is a lack of empirical evidence based on large datasets that allows a generalization of results (e.g. European Commission, 2008; Fagerberg et al., 2012). As Keupp et al., (2012:383) stated: "Specifically, we identified theoretical inconsistencies and knowledge gaps with regard to....the strategic management of process innovations...”. In this study we address the cluster of processoriented firms, those mainly focused on improving technological production processes and not products. Technological process innovation is defined as the adoption of technologically new or significantly improved production methods, including changes in equipment, organization or methods of product delivery, following the Oslo Manual. In table 1 we show the differing lines of enquiry, samples and gaps covered around the less studied process innovation phenomenon. See Table 1. 


\section{Insert Table 1 here}

For this purpose, we posit that there are firms across a very diverse set of industries that follow a different and specific pattern of innovation focused specifically on developing solely new technological processes. Or to put it another way, those firms can be specialized in specific stages of the value chain which are process-intensive, regardless of the type of product or industry to which they are affiliated. These are usually subcontractors or are firms positioned in low-value added stages of their product's value chain. They may also work for product developers, specializing only in production and process-based activities. Some firms are particularly oriented to developing process innovation capabilities by virtue of belonging to the industrial processing sector -including, for example, the oil industry, (Stadler, 2011)-. We also claim that other firms vary in the degree to which they are process oriented according to their positions in industry value chains. For instance, in the automobile industry whereas first-tier suppliers might be engaged in the co-development of new products with the final assemblers, or maybe just produce to the assemblers' designs, the second-tier metallic or plastic product contractors carry out the majority of the actual manufacturing processes. These second tier suppliers are mainly focused on efficiency and cost reduction because they work on products designed and developed by their customers. They are process-seekers or process-oriented firms, that is, those firms that usually just introduce only process, rather than product innovation. Their selection helps us to understand process without product interferences. Therefore, determining how process-oriented innovators' capabilities are organized, through the development of process innovation activities and their performance, constitutes a novelty in the innovation literature. The study of process-oriented innovators permits the better understanding of specific process innovation capabilities, activities and production-driven performance that are usually blurred with product innovation. 
Using the theory of complementarities from economics (Milgrom and Roberts, 1995) and management, related to the RBV (resource-based view) (Barney, 1991; Porter, 1996; Siggelkow, 2001), this paper addresses 4,608 process seekers or process-oriented innovators, which are those firms that introduced only process innovation, rather than product innovation, during a three-year period window in the 2004-2006 wave of the Community of Innovation Survey (CIS) in Spain. Results show that process innovation without including organizational or managerial innovation complements constrains innovative performance. Complex processbased innovation complementarities (such as positive synergies) result from the simultaneous development and integration of technical embodied knowledge, from purchasing technologically-improved machinery, and organizational innovations. Thus, managers focused on incremental process innovation by acquisition of external technology must maximize technological process-oriented innovative performance by engaging in complementary organizational innovations which reinforce technological process efforts. Process innovators, however, lack a strong internal innovation capability excessively dependent on acquiring machinery, compared to product innovators (e.g. Clausen et al., 2012).

\section{Literature review and hypotheses}

There are three main components representing process innovation capabilities, the latter directly related to production or process-driven innovative performance, defined as the improvement of production-based objectives, such as productivity, capacity or flexibility. Those constructs are purchasing technologically-improved machinery or embodied knowledge, organizational innovation and the joint integration of both, the latter producing 
complementarities or synergistic benefits. The rationale is based on the fact that (i) process innovation is related to the incorporation of new capital equipment (Jorgenson, 1966) and, (ii) technology must be integrated into the firm's organization and thus new organizational practices need to complement process ones (e.g. Edquist, Hommen, \& McKelvey, 2001; Ettlie, 1988).

\subsection{The embodied knowledge hypothesis: purchasing new machinery}

We posit that process-driven innovative performance is positively related to the introduction of embodied knowledge, through purchasing technologically-improved machinery. The rationale is based on the fact that process-oriented innovators present weak internal capabilities and depend heavily on acquiring external knowledge (e.g. Heidenreich, 2009), mainly from suppliers of technology (e.g. Hervas-Oliver et al., 2015). Thus, we argue that process innovation capabilities are related to "embodied technological change", incorporated into physical capital formation, rather than to formal R\&D investments (Pavitt, 1984; Robertson et al., 2012). Specifically, technological process-based innovation capabilities are formed by the incorporation of new capital equipment, such as processing machines, industrial robots or IT equipment (Edquist, 2001; Heidenreich, 2009; OECD, 2005), usually obtained by purchasing advanced machinery or computer hardware and software (Huang et al., 2010; OECD, 2005). This incorporation of embodied technology through purchasing technologically-improved machinery is thought to be one of the seminal drivers through which a firm renews and develops its process capabilities to innovate. Consequently, we expect that process-oriented innovators build up their technological process innovation capabilities by an intense use of embodied knowledge which is production-driven. Thus, our first hypothesis states that: 
Hypothesis 1: Process-oriented firms develop innovation capabilities mostly by acquiring external embodied technical knowledge which is positively related to production innovative performance

\subsection{Embodied knowledge is not enough: organizational innovation complements process innovation strategy.}

We also posit that the introduction of technology and the incorporation of new capital equipment is not enough by itself to activate and then further develop process innovation capabilities that improve performance, as is evidenced in Hervas-Oliver et al., (2015). Through this chain of thought, we argue that technology must be integrated into the firm's organization in order to capture all the potential benefits of process innovation. This idea could be seen as equivalent to those of synchronous innovation (Ettlie, 1988), organizational integration (Ettlie \& Reza, 1992), or the joint optimization of practices that are socially and technically-oriented (Cua, McKone, \& Schroeder, 2001). To understand issues related to process innovators and their innovative capabilities there is a need for a consideration of organizational innovation capabilities (Damanpour, 2014; Hollen, Van Den Bosch, \& Volberda, 2013). By organizational innovation we mean "the implementation of a new organizational method in the firm's business practices, workplace organization or external relations" (OECD, 2005: 177). In short, the introduction of organizational innovations by process innovators will improve the process innovation output, due to the reinforcement of process innovation capabilities to innovate (Edquist et al., 2001; Ettlie, 1988; Ettlie \& Reza, 1992; Fleck, 1994; Leonard-Barton \& Deschamps, 1988). Thus, we expect that introducing organizational innovation is also positively related to innovative production performance. The second hypothesis, therefore, relates organizational innovation to process-based 
innovation capabilities and addresses a main effect of organizational innovation in production or process-driven innovative performance. We stated second hypothesis as follows:

Hypothesis 2. Process-oriented firms develop innovation capabilities by the introduction of organizational innovations that are positively related to innovative production performance.

\subsection{Complementarities framework to position embodied knowledge and organizational innovation moderation effect}

Lastly, and following the above argument in hypothesis 1 and 2, we also posit that the joint introduction of organizational innovations and technology acquisition through embodied knowledge positively impacts production or process-driven innovative performance, due to the synergistic gains or complementarities generated from integrating technology and organization. First, Milgrom and Roberts (1990: 514) presented "complements" in a broader sense as a relation among groups of activities, stating that “...if the levels of any subset of activities are increased, then the marginal return to increases in any or all of the remaining activities rises". Similarly, Ichniowski et al. (1997) states that complementarity among practices implies that the magnitude of the performance effect of the entire system is larger than the sum of the marginal effects of adopting each practice individually. Activities that are mutually complementary need to be adopted together. If not, then the lack of coordination or integration may diminish returns. For instance, if a new flexible machine is installed, the marketing managers, without coordination, may underestimate the impact on job descriptions (Milgrom and Roberts, 1995). Empirical evidence on this point is provided by Ettlie and Reza (1992), who state that the successful adoption of process innovation, mostly acquiring new technologies for operations, are complemented by integration and coordination mechanisms in order to fully capture the value from process innovations and protect from imitation, underpinning a unique, significant restructuring of the firm's competitive advantage. 
Milgrom and Roberts (1995) and Ichniowski et al. (1997) focus on the notion of complementarities as systemic changes among organizational practices, thereby extending the contingency theory (Donaldson, 1996), in the sense that complementarities require fit between key organizational variables ${ }^{1}$.

Second, in the strategic management literature complementarities related to the RBV (e.g. Barney, 1991) and their key influence on a firm's innovation capabilities are recognized by the capabilities perspective (e.g. Stieglitz \& Heine, 2007). The RBV argues that joint adoption permits the integration of diverse assets or attributes and the construction of a consistent system of interrelated activities which mutually reinforce one another (Porter, 1996; Rivkin, 2000; Siggelkow, 2001). The integration of a range of assets, organizational processes, knowledge capabilities, and other potential sources of advantage deriving from the integration of process and organizational capabilities, results in a complex bundle of resources that underpin and configure repositories of knowledge, which in turn confer competitive advantage. Thus, as argued by Ennen \& Richter (2010) and Rivkin (2000), competitive advantage not only results from developing resources, but also from the capability to integrate them in a unique way: establishing entire systems of mutually reinforcing design elements enhances performance. All in all, we expect that the joint introduction of embodied knowledge and organizational innovations reinforce process-based capabilities and thus improve performance. Thus, the third hypothesis can be stated as follows, capturing a moderation or interaction effect for those complementarities:

Hypothesis 3. Process-oriented firms develop and reinforce innovation capabilities and positively influence production innovative performance through the creation of complementarities. The latter are formed by a complex integration and concurrent

\footnotetext{
${ }^{1}$ In this paper, however, super-modularity (Milgrom \& Roberts, 1995) is not analyzed.
} 
introduction of organizational innovations and the acquisition of external embodied technological knowledge.

\section{Empirical design}

\subsection{The CIS data source. Sample}

In order to focus on process innovation capabilities and their associated performance we need to be able to identify and select firms throughout different industries which exhibit an absence of product innovation. Our data has been drawn from the Spanish (Eurostat) CIS for 2006 and covers 28,649 firms, over the period 2004-2006. The CIS is extensively used in the UK, France, Spain, and Italy (e.g., Battisti \& Stoneman, 2010), among other European countries. It is the most used survey for measuring innovation. In Spain, the Survey is included in the General plan for statistics on science and technology promoted by the Statistical Office of the European Communities (Eurostat). The objective of the survey is to quantify the innovative activities of companies, among which, of particular note is the performance of $\mathrm{R} \& \mathrm{D}$, and to evaluate the results (innovations) and effects of such activities, being compulsory by Spanish Law. This statistical research extends to companies, with at least ten paid employees, in the NACE-2009 groups, from 01 to $96^{2}$.

Process innovation is predominantly based on cost reduction or the improvement of flexibility in production (e.g. Edquist et al., 2001). The output or dependent variable highlighted in our paper refers to the above mentioned process-oriented innovative performance or effects from innovation obtained by a firm following engagement in management and development of process innovation activities. In the Spanish CIS 2006, the question referring to output is as follows: "Please, indicate the impact or effect that your

\footnotetext{
2 More info at: http://www.ine.es/dyngs/INEbase/en/operacion.htm?c=Estadistica_C\&cid=1254736176755\&menu=metodologia\&idp=1254735576669
} 
innovation activities have had on your enterprise in the period 2004-2006". The impact or effect, defined as the innovative production performance, is depicted by four items: labour cost reduction, production flexibility, improvement of capacity, or a reduction of use of materials. Innovative performance is obtained from four variables addressing the effects of the introduction of new process activities by process-oriented innovators. The resulting scores from a principal component analysis (PCA) represent the innovative performance variable, which is made up of "improved production flexibility," "reduced unit labor costs," "increased capacity," and "reduced materials and/or energy per produced unit." The four original variables were ordered responses, represented on a scale from zero (none, no effect) to 3 (highest). Following this procedure, one single component from the analysis, through its scores, represents the dependent variable which explains $60.21 \%$ of the variance $(\mathrm{KMO}=$ $0.7172, \mathrm{p}<0.01)$. In order to triangulate results, confirmatory factor analysis verified the single component used as dependent variable. For the sake of brevity, results available upon request. See table 2 .

\section{Insert Table 2 here}

The study sample was reduced to 4,608 pure process or process-oriented innovators, as explained in the introduction. As the sample selection was based on one threshold (i.e. whether or not firms are solely process innovators), our results could suffer from additional selection bias and for this reason the two-step Heckman procedures (Heckman, 1979) were used and we found that the sample obtained did not suffer from selection bias ${ }^{3}$.

\subsection{Variables}

In respect of process activities or independent variables we employed two key indicators:

\footnotetext{
${ }^{3}$ More results available upon request
} 
(i) Embodied technology, or the purchasing technologically-improved machinery variable for process development, was captured by embodied technology expenditures per sales (Purchasing_machinery). This variable reflected the acquisition of advanced machinery, equipment and computer hardware or software, and addressed the "embodied hypothesis". Following the Vega-Jurado et al., (2008) procedure, the Purchasing_machinery variable was measured via an ordered 5 point-scale to better reflect its influence $(0: 0 ; 1: 0 \%<\mathrm{x}<=5 \% ; 2: 5 \%<$ $\mathrm{x}<=10 \% ; 3: 10 \%<\mathrm{x}<=50 \% ; 4:>50 \%)$.

(ii) Then, a variable referring to organizational innovation capabilities indicated whether a firm had introduced at least one new or improved organizational innovation during the research period. There are four different types of organizational innovation, as shown in table 2: -new business practices in the organization; -new knowledge management systems;-new organization methods for the workplaces;-new management models for external relations. This was depicted by the variable Organizational_innovation, as reported in table 2.

Control variables are shown in Table 2, including investments in intramural and extramural R\&D activities, as well as sector classification (Industry_NACE_code), including the 58 2digit NACE-93 industry classification as dummies, ranging from the 14 to 74 2-digit NACE93 codes (59 industries).

In addition, common method response bias was tested using Harman's single factor test (Greene \& Organ, 1973), but no common method variance was located. More results and information are available upon request. 


\section{Results and discussion}

\subsection{Findings}

See table 3 for descriptive statistics. Three OLS were run for three specifications, using process-oriented innovative performance as the dependent variable for the sample ${ }^{4}$ (See table 4).

\section{Insert Table 3 here}

\section{Insert Table 4 here}

According to table 4, the three specifications offer a good fit (adjusted $\mathrm{R}^{2}$ ranging from 0.21 to 0.23 ). The results in table 4, corresponding to Specification 1, indicate that investments in internal $\mathrm{R} \& \mathrm{D}$ activities (Internal_R\&D_expenditures) do not influence innovative performance. This result is repeated in all subsequent specifications. The coefficients are negative, although they are not statistically significant. Similarly, in all specifications, the variable External_R\&D_expenditures is not significant, meaning that the acquisition of $\mathrm{R} \& \mathrm{D}$ from external sources does not render any production returns for process innovators. This result is also observed in the other specifications. However, there is one key variable that reflects the acquisition of embodied knowledge, Purchasing_machinery, which contributes to increasing production innovation performance (coefficient $0.123,0.137$ and 0.085 in specifications 1 to 3 , respectively; all of them significant at $p<0.01$ ). The Organizational_innovation variable, which addresses whether the firm has also introduced organizational innovation activities, does contribute positively to improving production innovation performance, as there is a positive and significant coefficient in the first and second specifications $(0.075,0.058$, respectively, $\mathrm{p}<0.01)$.

\footnotetext{
${ }^{4}$ The Inverse Mill ratio from the Probit model turns out to be non-significant ( $p>5 \%$ ), suggesting that the sample obtained does not suffer from selection biases.
} 
Lastly, there are important results for an interaction variable that captures complementarities among innovation capabilities, as observed in specification 3. As such, the effect of the acquisition of embodied knowledge and its process technology capabilities is positively moderated; that is to say, there are complementarities at work thanks to the introduction of new management practices (i.e. organizational innovation) (Organizational_innovation_x_ Purchasing_machinery). This indicates that an improvement in innovative performance is obtained from simultaneously co-adopting the acquisition of embodied knowledge and organization innovation activities within the firm (specification 3, 0.082 at $\mathrm{p}<0.05$ ). Following Venkatraman (1989), our technological and organizational integration or complement refers to fit as moderation, that is, the impact of the predictor (technology) varies across the different levels of the moderator (organizational innovation). In this sense, we also proceed to confirm that the positive joint effect actually exists. Following Aiken and West (1991), we plot the innovative performance against the Purchasing_machinery for the two different values of Organizational_innovation $(0-1 ; 1$ for organizational innovators and 0 otherwise). See figure 1. Results show how innovative performance increases with the acquisition of embodied technology (Purchasing_machinery variable). This increase is larger when organizational innovation introduction occurs, confirming the third hypothesis. See figure 1.

\section{Insert Figure 1 here}

In short, R\&D (internal or external) activities do not explain any innovative returns, in line with Hervas-Oliver et al., (2015) and Stadler (2011). 


\subsection{Discussion of results}

\subsubsection{Why only process innovation?}

We posit that firm heterogeneity constrains that this one-size-fits-all works in all different types of firms, especially in those that are process seekers or process-oriented innovators versus product innovators. In fact, usually, most of studies utilize samples containing firms that perform both process and product innovation or impose "industry representative innovation strategy" upon firms, neglecting heterogeneity that drives different innovation patterns, and thus making the analysis of the specific process innovation strategy difficult: these common procedures are not precise enough for understanding process innovation capabilities and performance, especially among process-oriented firms. Our study goes a step further and isolates process innovation by studying process-seekers or process-oriented firms, their capabilities and performance consequences.

Our results show potential contributions for the innovation literature. In general, this study's results show how different process innovation's capabilities and performance are, from those of product innovation. First, this study's results coincide with those of Clausen, Pohjola, Sapprasert, \& Verspagen, (2012), which argue that those firms principally pursuing process innovation are innovators that rely mostly on suppliers of machinery and equipment as knowledge sources for their innovations belong to the supplier-based strategy, in line with Pavitt's (1984) taxonomy based on industries.

\subsubsection{Process capabilities for innovation: how strong are they?}

Second, as expected, the acquisition of embodied knowledge or purchasing of technologically-improved machinery is a major determinant of process-based innovation capabilities, confirming what has previously appeared in the literature (Edquist, 2001; Heidenreich, 2009). This is a major source of new process capabilities but also a signal that 
there is an existence of weak internal capabilities, which are substituted by an intensive process of accessing external sources of knowledge, mainly through the acquisition of embodied knowledge for incremental process innovation to occur. Similarly, this result also confirms what literature has previously stated: the pattern of process innovation suggests the existence of weak internal capabilities, which are substituted by an intensive process of accessing external sources of knowledge, mainly through the acquisition of embodied knowledge (Hervas-Oliver et al., 2015; Heidenreich, 2009; Hervas-Oliver et al., 2011; Jorgenson, 1966; Pavitt, 1984).

\subsubsection{Process innovation requires organizational complements!}

Third, this paper contributes by pointing out that, for process innovation, combining the incorporation of equipment purchased from external suppliers with organizational innovations to integrate technology into organizations, results in a superior performance: the simultaneous development (positive moderation) by process innovators of the acquisition of embodied technology and its organizational integration is positively related to processoriented innovative performance, showing complementarities by technology and nontechnology innovation integration. This results in reduced costs and also materials per produced unit and improvements in production flexibility and capacity. Thus, the present study contributes to the literature by showing that only embodied technology acquisition by itself is necessary but not sufficient. These results confirm the fact that process innovation capability development is related to learning-by-doing, and linked to innovation strategies which are believed to be less developed compared to strategies for product innovation (Pisano, 1997). In process innovation strategies, trial and error and small changes are important. These results are similar to those found in Clausen et al., (2012) or Stadler (2011), among others. 


\section{References}

Abernathy, W. J., \& Utterback, J. M. (1978). Patterns of innovation in technology. Technology Review, 80(7), 40-47.

Barge-Gil, A., Jesus Nieto, M., \& Santamaria, L. (2011). Hidden innovators: The role of non-R\&D activities. Technology Analysis \& Strategic Management, 23(4), 415-432.

Barney, J. (1991). Firm resources and sustained competitive advantage. Journal of Management Studies, 17(1), 99-120. http://doi.org/10.1177/014920639101700108

Battisti, G., \& Stoneman, P. (2010). How innovative are UK firms? evidence from the fourth UK community innovation survey on synergies between technological and organizational innovations. British Journal of Management, 21(1), 187-206.

Benner, M. J., \& Tushman, M. (2002). Process management and technological innovation: A longitudinal study of the photography and paint industries. Administrative Science Quarterly, 47(4), 676-707.

Benner, M. J., \& Tushman, M. L. (2003). Exploitation, exploration, and process management: The productivity dilemma revisited. Academy of Management Review, 28(2), 238-256.

Cabral, R., \& Leiblein, M. J. (2001). Adoption of a process innovation with Learning-by-Doing: Evidence from the semiconductor industry. The Journal of Industrial Economics, 49(3), 269-280.

Clausen, T., Pohjola, M., Sapprasert, K., \& Verspagen, B. (2012). Innovation strategies as a source of persistent innovation. Industrial and Corporate Change, 21(3), 553-585.

Cua, K. O., McKone, K. E., \& Schroeder, R. G. (2001). Relationships between implementation of TQM, JIT, and TPM and manufacturing performance. Journal of Operations Management, 19(6), 675-694.

Damanpour, F. (2014). Footnotes to research on management innovation. Organization Studies, 35(9), 12651285 .

Donaldson L. 1996. For positivist organization theory: Proving the hard core. Sage Publications Ltd:

Edquist, C. (2001). Innovation policy-a systemic approach. In The Globalizing Learning Economy. (Oxford University Press, pp. 219-237).

Edquist, C., Hommen, L., \& McKelvey, M. D. (2001). Innovation and employment: Process versus product innovation. Edward Elgar Publishing.

Ennen, E., \& Richter, A. (2010). The whole is more than the sum of its parts - or is it? A review of the empirical literature on complementarities in organizations. Journal of Management, 36(1), 207-233.

Escribano, A., Fosfuri, A., \& Tribo, J. A. (2009). Managing external knowledge flows: The moderating role of absorptive capacity. Research Policy, 38(1), 96-105.

Ettlie, J. E. (1988). Taking charge of manufacturing: how companies are combining technological and organizational innovations to compete successfully. Jossey-Bass Inc., Publishers.

Ettlie, J. E., \& Reza, E. M. (1992). Organizational integration and process innovation. Academy of Management Journal, 35(4), 795-827.

European Commission. (2008). European Innovation Scoreboard 2007. Comparative analysis of Innovation Performance. PRO INNO Europe/INNO-Metrics.

Evangelista, R., Iammarino, S., Mastrostefano, V., \& Silvani, A. (2002). Looking for regional systems of innovation: evidence from the Italian innovation survey. Regional Studies, 36(2), 173-186.

Evangelista, R., \& Vezzani, A. (2010). The economic impact of technological and organizational innovations. A firm-level analysis., 39(10), 1253-1263.

Fagerberg, J., Mowery, D. C., \& Nightingale, P. (2012). Introduction: The heterogeneity of innovationevidence from the Community Innovation Surveys. Industrial and Corporate Change, 21(5), 1175-1180.

Fleck, J. (1994). Learning by trying: the implementation of configurational technology. Research Policy, 23(6), 637-652.

Frishammar, J., Kurkkio, M., Abrahamsson, L., \& Lichtenthaler, U. (2012). Antecedents and consequences of firms' process innovation capability: a literature review and a conceptual framework. Engineering Management, IEEE Transactions on, 59(4), 519-529.

Greene, C. N., \& Organ, D. W. (1973). An evaluation of causal models linking the received role with job satisfaction. Administrative Science Quarterly, 18, 95-103.

Heckman, J. J. (1979). Sample selection bias as a specification error. Econometrica. Journal of the Econometric Society, 153-161. 
Heidenreich, M. (2009). Innovation patterns and location of European low-and medium-technology industries. Research Policy, 38(3), 483-494.

Hervas-Oliver, J. L., Albors-Garrigos, J., \& Gil-Pechuan, I. (2011). Making sense of innovation by R\&D and non-R\&D innovators in low technology contexts: A forgotten lesson for policymakers. Technovation, 31(9), 427-446.

Hervas-Oliver, J. L., Sempere-Ripoll, F., Boronat-Moll, C., \& Rojas, R. (2015). Technological innovation without R\&D: unfolding the extra gains of management innovations on technological performance. Technology Analysis \& Strategic Management, 27(1), 19-38. http://doi.org/10.1080/09537325.2014.944147

Hervas-Oliver, J. L., \& Sempere-Ripoll, F. (2015). Disentangling the influence of technological process and product innovations. Journal of Business Research, 68(1), 109-118.

Hollander, S. (1965). The sources of increased efficiency: A study of DuPont rayon plants (Vol. 1).

Hollen, R., Van Den Bosch, F. A., \& Volberda, H. W. (2013). The Role of Management Innovation in Enabling Technological Process Innovation: An Inter-Organizational Perspective. European Management Review, 10(1), $35-50$.

Huang, C., Arundel, A., \& Hollanders, H. (2010). How firms innovate: R\&D, non-R\&D, and technology adoption. UNU-MERIT WORKING Paper Series, (27).

Hutcheson, P., Pearson, A. W., \& Ball, D. F. (1995). Innovation in process plant: a case study of ethylene. Journal of Product Innovation Management, 12(5), 415-430.

Ichniowski C, Shaw K, Prennushi G. 1997. The effects of human resource practices on manufacturing performance: A study of steel finishing lines. American Economic Review 87 (3): 291-313

Jorgenson, D. W. (1966). The embodiment hypothesis. The Journal of Political Economy, 1-17.

Keupp, M. M., Palmie, M., \& Gassmann, O. (2012). The strategic management of innovation: a systematic review and paths for future research. International Journal of Management Reviews, 14(4), 367-390.

Kline, S. J., \& Rosenberg, N. (1986). An overview of innovation. The Positive Sum Strategy: Harnessing Technology for Economic Growth, 275, 305.

Knight, K. E. (1967). A descriptive model of the intra-firm innovation process. The Journal of Business, 40(4), 478-496.

Lager, T. (2002). Product and process development intensity in process industry: A conceptual and empirical analysis of the allocation of company resources for the development of process technology. International Journal of Innovation Management, 6(02), 105-130.

Laursen, K., \& Salter, A. (2006). Open for innovation: the role of openness in explaining innovation performance among UK manufacturing firms. Strategic Management Journal, 27(2), 131-150.

Leonard-Barton, D., \& Deschamps, I. (1988). Managerial influence in the implementation of new technology. Management Science, 34(10), 1252-1265.

Linton, J. D., \& Walsh, S. T. (2008b). A theory of innovation for process-based innovations such as nanotechnology. Technological Forecasting and Social Change, 75(5), 583-594.

Milgrom, P., \& Roberts, J. (1995). Complementarities and fit strategy, structure, and organizational change in manufacturing. Journal of Accounting and Economics, 19(2), 179-208.

Nelson, R. R., \& Winter, S. G. (1982). An evolutionary theory of economic change. Belknap press.

OECD. (2005). Oslo manual: Guidelines for collecting and interpreting innovation data. OECD Publishing.

OECD. (2009). Innovation in Firms. A microeconomic Perspective. Paris: OECD publishing.

Pavitt, K. (1984). Sectoral patterns of technical change: towards a taxonomy and a theory. Research Policy, 13(6), 343-373.

Pisano, G. P. (1994). Knowledge, integration, and the locus of learning: An empirical analysis of process development. Strategic Management Journal, 15(S1), 85-100.

Podsakoff, N. P., Podsakoff, P. M., MacKenzie, S. B., \& Klinger, R. L. (2013). Are we really measuring what we say we're measuring? Using video techniques to supplement traditional construct validation procedures. Journal of Applied Psychology, 98(1), 99.

Porter, M. E. (1996). What is strategy? Harvard Business Review, 74(6), 61-78.

Reichstein, T., \& Salter, A. (2006). Investigating the sources of process innovation among UK manufacturing firms. Industrial and Corporate Change, 15(4), 653-682.

Rivkin, J. W. (2000). Imitation of complex strategies. Management Science, 46(6), 824-844.

Robertson, P. L., Casali, G. L., \& Jacobson, D. (2012). Managing open incremental process innovation: Absorptive Capacity and distributed learning. Research Policy, 41(5), 822-832.

Rönnberg-Sjödin, D., Eriksson, P. E., \& Frishammar, J. (2011). Open innovation in process industries: a lifecycle perspective on development of process equipment. Int. J. Technology Management, 56(2/3/4), 225240.

Siggelkow, N. (2001). Change in the presence of fit: The rise, the fall, and the renaissance of Liz Claiborne. Academy of Management Journal, 44(4), 838-857. 
Stadler, C. (2011). Process Innovation and Integration in Process-Oriented Settings: The Case of the Oil Industry. Journal of Product Innovation Management, 28(s1), 44-62.

Stieglitz, N., \& Heine, K. (2007). Innovations and the role of complementarities in a strategic theory of the firm. Strategic Management Journal, 28(1), 1-15.

Utterback, J. M. (1996). Mastering the dynamics of innovation. Harvard Business Press.

Vega-Jurado, J., Gutiérrez-Gracia, A., Fernández-de-Lucio, I., \& Manjarrés-Henríquez, L. (2008). The effect of external and internal factors on firm's product innovation. Research Policy, 37(4), 616-632.

Volberda, H. D., Van Der Bosch, F. A. J., \& Heij, C. V. (2013). Management Innovation: Management as Fertile Ground for Innovation. European Management Review, 10(1), 1-15.

Womack, J. P., Jones, D. T., \& Roos, D. (1990). The machine that changed the world: the story of lean production. Scribner. 